\title{
Zircon U-Pb ages of granites at Changba and Huangzhuguan in western Qinling and implications for source nature
}

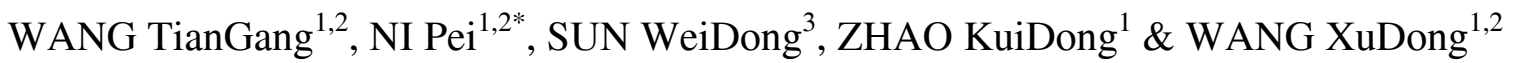 \\ ${ }^{1}$ School of Earth Sciences and Engineering, State Key Laboratory for Mineral Deposits Research, Nanjing University, Nanjing 210093, China; \\ ${ }^{2}$ Institute of Geo-Fluids, Nanjing University, Nanjing 210093, China; \\ ${ }^{3}$ Key Laboratory of Isotope Geochronology and Geochemistry, Guangzhou Institute of Geochemistry, Chinese Academy of Sciences, Guangzhou \\ 5100640, China
}

Received July 12, 2010; accepted September 6, 2010

\begin{abstract}
Mesozoic granitoids are widespread in the Qinling-Dabie-Sulu orogenic belt. Precise U-Pb dating on these granitoids can reveal the evolution of the continental collision orogen and thus provide information on the nature of magma sources. This study presents zircon LA-ICP-MS U-Pb dating and whole-rock geochemical analyses for two intrusions at Changba and Huangzhuguan in western Qinling. Zircon U-Pb ages for central and marginal phases of the Huangzhuguang intrusion are 214 $\pm 1 \mathrm{Ma}$ and 213 $\pm 3 \mathrm{Ma}$, respectively. Zircons from the Changba intrusion yield a dominant cluster with an U-Pb age of $213 \pm 2 \mathrm{Ma}$. Collectively, these ages are younger than ages of 220 to $240 \mathrm{Ma}$ for ultrahigh-pressure metamorphism due to the continental collision between the South China Block and the North China Block, corresponding to syn-exhumation magmatism. Some inherited zircons occur in the Changba intrusion, yielding a weighted mean of ${ }^{206} \mathrm{~Pb} /{ }^{238} \mathrm{U}$ ages at $757 \pm 14 \mathrm{Ma}$. This indicates that the Changba intrusion has the crustal source of mid-Neoproterozoic ages and a tectonic affinity to the South China Block. Geochemically, the two intrusuons are both rich in LILE and LREE but depleted in HFSE and HREE, similar to arc-type igneous rocks. The Huangzhuguang intrusion exhibits linear correlations between $\mathrm{SiO}_{2}$ and the other major oxides, implying chemical evolution from a cognate magma source. It contains mafic enclaves, suggesting possible mixing of felsic-mafic magmas. The Changba granite is rich in $\mathrm{Si}$ and $\mathrm{K}$ but poor in Fe and $\mathrm{Mg}$ as well as has a high value of Fe*, suggesting strong differentiation of granitic magma. Therefore, the two intrusions were derived from the Late Triassic anatexis of the continental crust of different compositions in the northern margin of South China Block. This process may be coupled with exhumation of the subducted continental crust in the stage of late collision.
\end{abstract}

Qinling orogen, continental collision, granite, zircon U-Pb dating, whole-rock geochemistry, syn-exhumation magmatism

Citation: Wang T G, Ni P, Sun W D, et al. Zircon U-Pb ages of granites at Changba and Huangzhuguan in western Qinling and implications for source nature. Chinese Sci Bull, 2011, 56: 659-669, doi: 10.1007/s11434-010-4319-5

The Qinling orogen is an important part of the central orogenic belt in China, and experienced three main evolutionary stages: (1) the formation of Precambrian basements from Archean to Neoproterozoic; (2) the evolution of plate tectonics from oceanic subduction to continental collision during the Early Paleozoic to Early Mesozoic; and (3) intracontinental orogeny during the Jurassic to Cretaceous [1-7]. The Triassic collision between the South China Block and the North China Block caused the Mianlue suture

*Corresponding author (email: peini@nju.edu.cn) in the Qinling orogen, widespread high-pressure (HP) to ultrahigh-pressurer (UHP) metamorphism but few syn-collisional magmatic rocks in the Dabie-Sulu orogenic belt [5-7]. In contrast, there are widespread occurrences of Triassic granitic rocks in the Qinling orogen (Figure 1), forming a belt of 400-km-long granitoids along the Mianlue suture $[1,3]$. These granitoids provide the geological record of orogenic formation and evolution. Petrogenetically, they are considered as either synorogenic granitoids [8] or post-collision granitoids [9]. Precise dating of these Mesozoic granitoid intrusions can reveal the processes of continental 


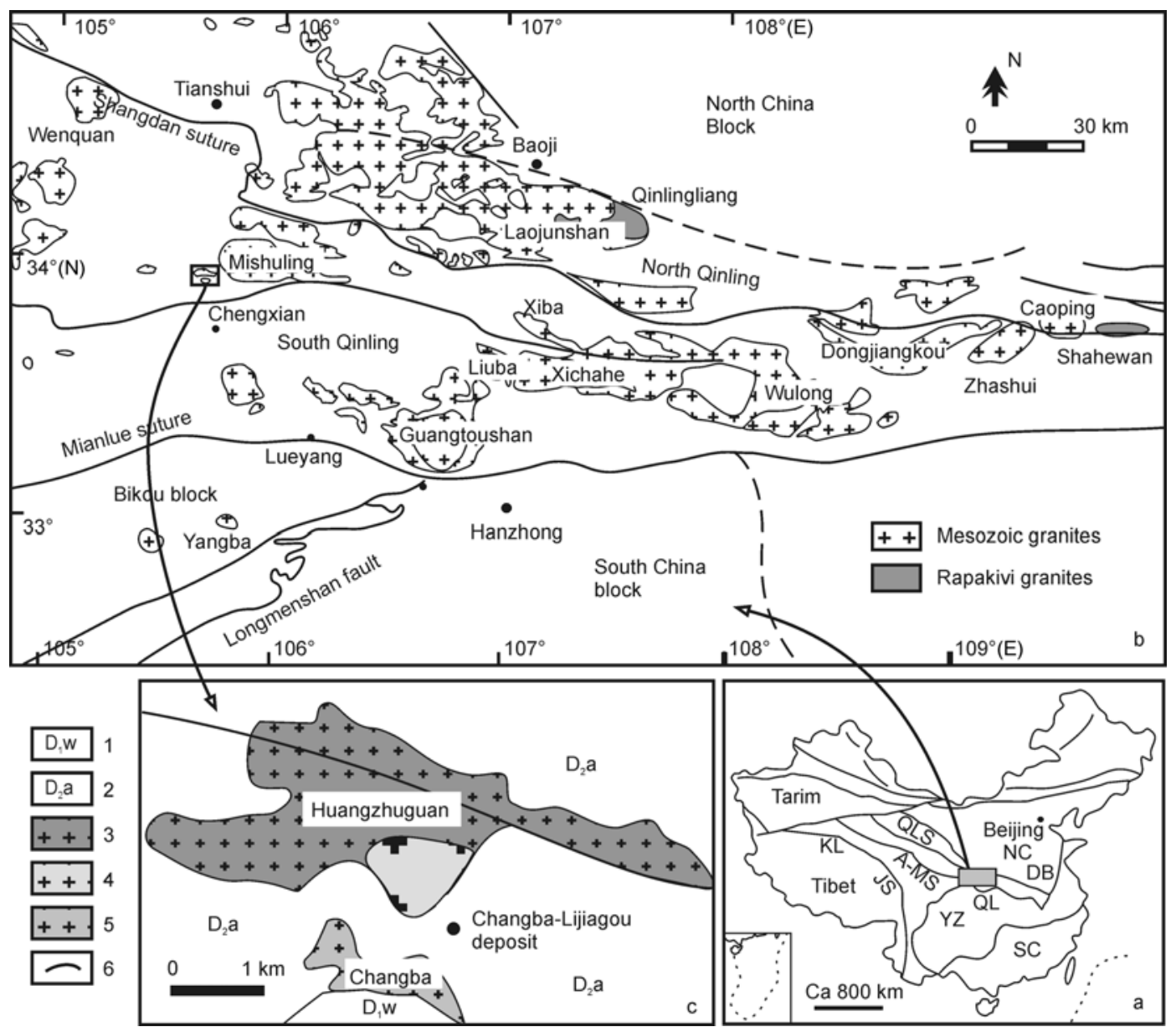

Figure 1 a, Geological sketch map of China, showing major tectonic units; b, geological map showing distribution of Triassic granites in the Qinling orogen (after Zhang et al. [23]); c, geological map of the Changba and Huangzhuguang granites in western Qinling. Inset shows location of study area in China. Abbreviations: NCB, North China Block; SC, South China Block; KL, Kunlun Mountains; QLS, Qilian orogen; QL, Qinling orogen; DB, Dabie orogen. 1, Lower Devonian strata; 2, Middle Devonian strata; 3, marginal phase of HZG intrusion; 4, central phase of HZG intrusion; 5, CB intrusion; 6, fault.

collision in the Qinling orogen and thus provide insights into the nature of magma source.

With extensive application of in-situ laser ablation inductively coupled plasma mass spectroscopy (LA-ICP-MS) zircon U-Pb dating, many qualified ages have been obtained for granites from eastern Qinling and its adjacent regions (Table 1), but there are only limited dates for granites in western Qinling. This study presents took the Changba (CB) and Huangzhuguan (HZG) granites in western Qinling for precise in-situ zircon U-Pb dating and whole-rock geochemistry analysis. The results are used to identify the tectonic setting of granitic magmatism and reveal the nature of their sources.

\section{Geological setting and samples}

The Qinling-Dabie-Sulu orogenic belt marks the Triassic suture between the North China Block and and South China Block, with the occurrences of UHP metamorphism rocks in the Dabie-Sulu orogenic belt $[3,5-7,10]$. The geologic framework of the Qinling orogen is built up through interaction of three blocks, which are the North China (i.e., North Qinling), South Qinling and South China blocks. They are separated by two lithotectonic zones. The northern zone is bordered by the Shangdan suture, and the southern zone is bordered by the Mianlue suture in the west and the Bashan fault in the east $[1,3,11]$. The North Qinling Block is located north of the Shangdan suture, and comprises middle Paleozoic medium-grade meta-sedimentary and meta-volcanic rocks [10]; The South Qinling Block is bounded by the two lithotectonic zones, and is predominately by the Late Paleozoic medium-grade meta-sedimentary and metavolcanic rocks [12] and the Triassic granitoids [10,11]. South of the Mianlue suture is the South China Block.

The Mianlue ophiolite complex mainly consists of strongly sheared metabasalt, cumulate gabbro, ultramafic rocks and radiolarian cherts [11]. Some of the metabasalts display geochemical features of normal mid-ocean ridge basalts (N-MORB) $[13,14]$. They underwent metamorphism 
in the Triassic (242 to $221 \mathrm{Ma}$ ) [15], which is consistent with UHP metamorphic ages of 240 to $225 \mathrm{Ma}$ in the Dabie-Sulu orogenic belt [7,16-22].

In the Triassic, continental collision of the South China Block and the North China Block in the Qinling orogen occurred along the Mianlue suture, with formation of a huge granitoid belt but no report of UHP metamorphic rocks in this region. This 400-km-long granitoid belt covers an area of ca. $6000 \mathrm{~km}^{2}$, which mainly outcrops in western and eastern Qinling, and also is found on the northwestern margin of the South China block. The granites in eastern Qinling generally are preserved as multi-stage granitic complexes, such as the Dongjiangkou, Wulong, Guangtoushan and Baoji suites, which were emplaced into the Paleozoic low-grade metamorphic sequences as an irregularly shaped intrusive batholith. In western Qinling, granites were emplaced into the Paleozoic low-grade metamorphic sequences as an isolated, ellipsoidal intrusive pluton. Granites at the northwestern margin of the South China Block outcrop as undeformed small intrusions hosted by an old metamorphic complex.

The CB and HZG intrusions occur $20 \mathrm{~km}$ north of Chengxian, Gansu Province. The dominant fault in the district is the Huangzhuguan fault, and granitoids such as the Mishuling and Huangzhuguan intrusions were emplaced along this fault. The HZG intrusion outcrops irregularly and covers an area of $17 \mathrm{~km}^{2}$. It was emplaced into middle Devonian strata. Two different phases were identified. The central phase is massive, hypidiomorphic granular or porphyritic-likediorite-granodiorite that is composed of plagioclase (40 vol.\%), microcline (30 vol.\%), quartz (10 vol.\%) (Figure $2 \mathrm{a}, \mathrm{d})$, amphibole (10 vol.\%), biotite (5 vol.\%). The marginal phase is massive, fine-grained granite that is com- posed of plagioclase (40 vol.\%), quartz (30 vol.\%), microcline (15 vol.\%), biotite (10 vol.\%) and minor amphibole, with accessory minerals of apatite, zircon, and sphene (Figure 2b,e). Mafic micro-granular enclaves were mainly observed in the central phase, which have variable diameters of 1 to $70 \mathrm{~cm}$, and ellipsoidal, lenticular shapes. The mafic enclaves have hypidiomorphic to allotriomorphic textures and contain plagioclase (40 vol.\%), amphibole (30 vol.\%) and biotite (20 vol.\%), with minor acicular apatite. The CB intrusion to the south of the HZG intrusion outcrops in a dumbbell shape, and was emplaced into middle and lower Devonian strata, covering an area of $2.4 \mathrm{~km}^{2}$. It is dominantly composed of medium to fine-grained two-mica granites, which are massive, hypidiomorphic to panallotriomorphic granular. The CB intrusion consists mainly of microcline (35 to $45 \%$ ), plagioclase (20 to $25 \%$ ), quartz (20 to $25 \%$ ), biotite $(5 \%)$, and muscovite $(5 \%)$, with accessory apatite, zircon (Figure 2c,f).

\section{Analytical methods}

Zircons were separated using a conventional heavy liquid and magnetic technique from fresh rocks of the HZG and $\mathrm{CB}$ intrusions, and then hand-picked under a binocular microscope with consideration of size, clarity, color and morphology. These zircon crystals were mounted in resin and then polished to expose their centers. Internal structures of zircon grains were imaged by cathodoluminescence (CL) prior to analysis, using a JEOL JXA-8100 microprobe at State Key Laboratory for Mineral Deposit Research, Nanjing University (Figure 3).

LA-ICP-MS zircon U-Pb dating was conducted at State

Table 1 Formation ages of the Early Mesozoic granitoid intrusions in the Qinling Mountains region

\begin{tabular}{|c|c|c|c|c|c|}
\hline & District & Measuring object & Age (Ma) & Method & Reference \\
\hline \multirow{11}{*}{ Eastern Qinling } & Qinlingliang & zircon & 217 & $\mathrm{U}-\mathrm{Pb}$ & [24] \\
\hline & Taibailiang & hornblende & 216 & ${ }^{40} \mathrm{Ar} /{ }^{39} \mathrm{Ar}$ & [25] \\
\hline & Laojunshan & zircon & 214 & $\mathrm{U}-\mathrm{Pb}$ & [24] \\
\hline & Shahewan & zircon & 212 & $\mathrm{U}-\mathrm{Pb}$ & [26] \\
\hline & Shahewan & biotite & 209 & ${ }^{40} \mathrm{Ar} /{ }^{39} \mathrm{Ar}$ & [27] \\
\hline & Caoping & biotite & 217 & ${ }^{40} \mathrm{Ar} /{ }^{39} \mathrm{Ar}$ & {$[25]$} \\
\hline & Xichahe & zircon & $213.6 \pm 2.2$ & $\mathrm{U}-\mathrm{Pb}$ & [29] \\
\hline & Dongjiangkou & biotite & 198 & ${ }^{40} \mathrm{Ar} /{ }^{39} \mathrm{Ar}$ & [25] \\
\hline & Xiba & zircon & 201 & $\mathrm{U}-\mathrm{Pb}$ & [25] \\
\hline & Liuba & zircon & 221 & $\mathrm{U}-\mathrm{Pb}$ & [25] \\
\hline & Guangtoushan & zircon & $206 \sim 220$ & $\mathrm{U}-\mathrm{Pb}$ & {$[8]$} \\
\hline \multirow{2}{*}{ Northwestern margin of Yangtze } & Yangba & zircon & 215 & $\mathrm{U}-\mathrm{Pb}$ & {$[30]$} \\
\hline & Nanli & zircon & 224 & $\mathrm{U}-\mathrm{Pb}$ & {$[31]$} \\
\hline \multirow{3}{*}{ Western Qinling } & Zhiliguan & zircon & 245 & $\mathrm{U}-\mathrm{Pb}$ & {$[33]$} \\
\hline & Xiahe & zircon & 238 & $\mathrm{U}-\mathrm{Pb}$ & {$[33]$} \\
\hline & Mishuling & zircon & $212.9 \pm 2.6$ & $\mathrm{U}-\mathrm{Pb}$ & [34] \\
\hline
\end{tabular}



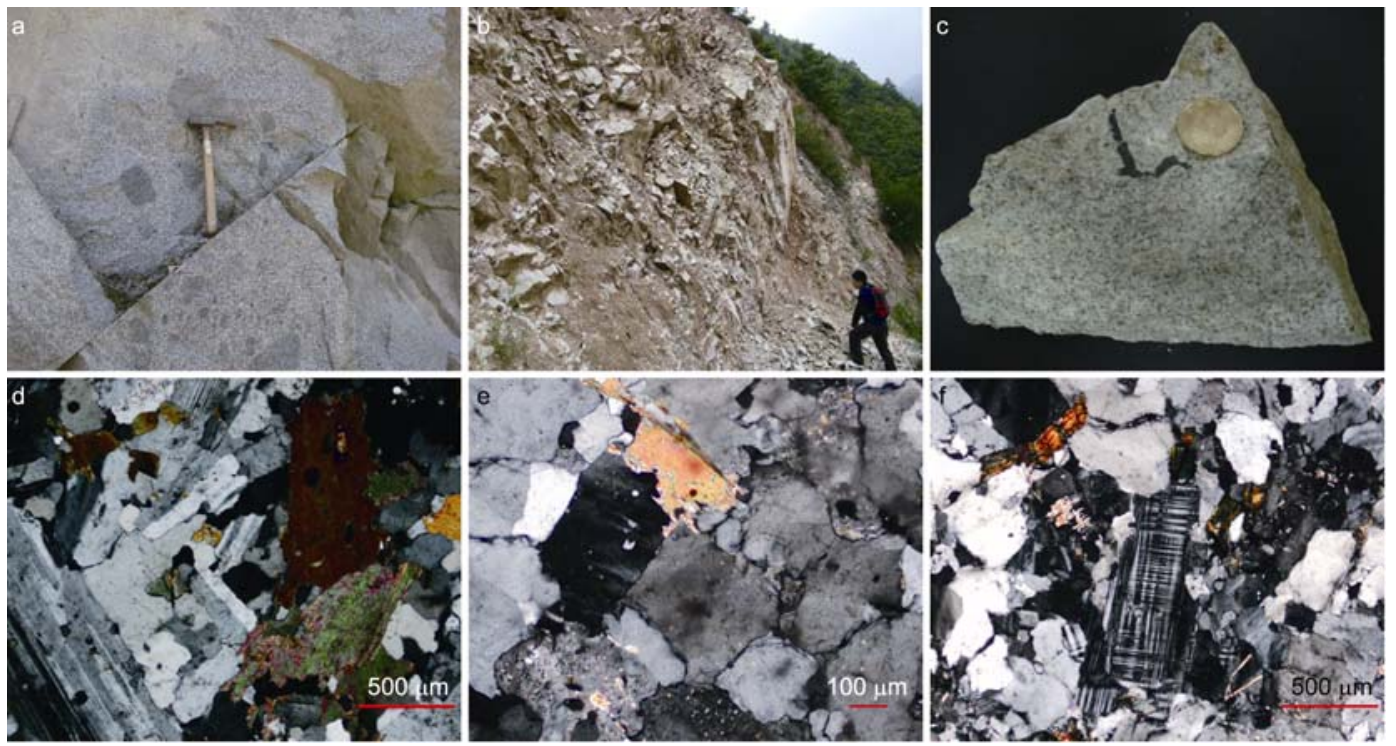

Figure 2 a, Field photo of HZG intrusion, central phase; b, field photo of HZG intrusion, marginal phase; c, photo of hand specimen from CB intrusion; d, photomicrograph of HZG intrusion, central phase; e, photomicrograph of HZG intrusion, marginal phase; $\mathrm{f}$, photomicrograph of CB intrusion.
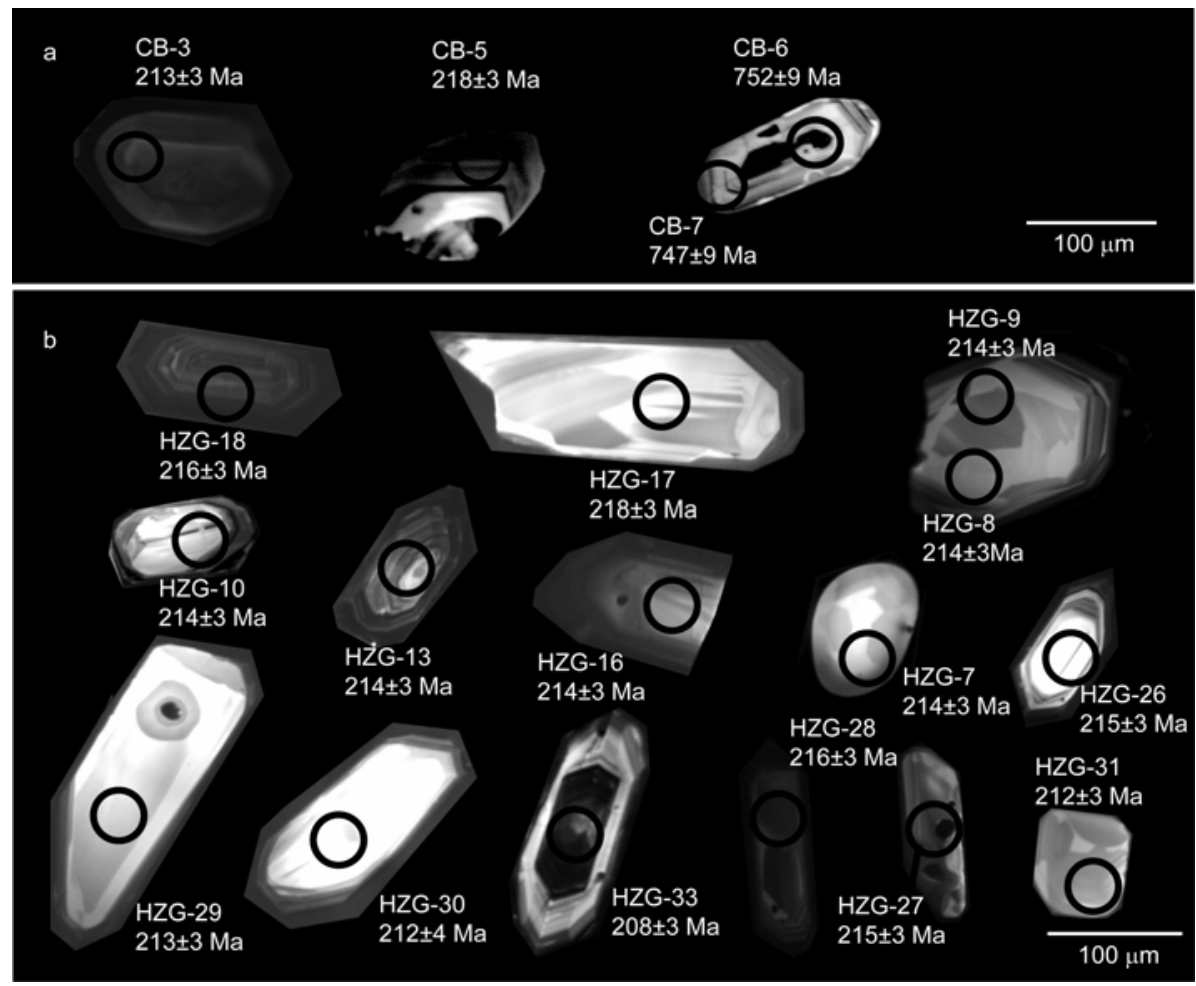

Figure 3 CL electron image of zircon from CB (a) and HZG (b) intrusions.

Key Laboratory for Mineral Deposits Research, Nanjing University, using an Agilent 7500a ICP-MS attached to a New Wave $213 \mathrm{~nm}$ laser ablation system, with spot sizes of $30 \mu \mathrm{m}$ to $38 \mu \mathrm{m}$ and a repetition rate of $5 \mathrm{~Hz}$. A homogeneous standard zircon, GEMOC GJ-1 ${ }^{207} \mathrm{~Pb} /{ }^{206} \mathrm{~Pb}$ age of $608.5 \pm 1.5 \mathrm{Ma}$ ) was used to correct the mass discrimination of the mass spectrometer and residual elemental fractiona- tion. A near-concordant standard zircon, Mud Tank (intercept age $732 \pm 5 \mathrm{Ma}$ ) was used as the internal standard to optimize reproducibility and instrument stability. Details of analytical methods and standards are similar to $\mathrm{He}$ et al. [35]. Data were processed using the software package GLITTER (ver.4.4) (www.mq.edu.au/GEMOC) and program ISOPLOT (ver. 2.49) [36], and common lead 
corrections were made adopting the method described by Andersen [37].

Major and trace elements were analyzed by ICP-AES and ICP-MS (Finnigan Element 2), respectively. Analyses of Chinese national rock standards indicate that analytical precision and accuracy for major elements are generally better than $2 \%$. For trace element analysis, sample powders were digested using an $\mathrm{HF}+\mathrm{HNO}_{3}$ mixture in high-pressure Teflon bombs at $190{ }^{\circ} \mathrm{C}$ for 48 hours. Analytical precision was better than $5 \%$.

\section{Results}

\subsection{Crystallization ages of HZG and CB intrusions}

CL images of representative zircons from the $\mathrm{HZG}$ and $\mathrm{CB}$ intrusions are shown in Figure 3. The LA-ICP-MS U-Pb isotopic analytical results are given in Table 2, and graphically presented in Figures 4 and 5. Zircons from the HZG and $\mathrm{CB}$ intrusions are prismatic and generally have well-developed oscillatory zoning (Figure 3). Fifty zircons

Table 2 Zircon LA-ICP-MS U-Pb results for CB and HZG intrusion ${ }^{\text {a) }}$

\begin{tabular}{|c|c|c|c|c|c|c|c|c|c|c|c|}
\hline Sample & $\mathrm{Th}\left(\mu \mathrm{g} \mathrm{g}^{-1}\right)$ & $\mathrm{U}\left(\mu \mathrm{g} \mathrm{g}^{-1}\right)$ & $\mathrm{Th} / \mathrm{U}$ & ${ }^{207} \mathrm{~Pb} /{ }^{206} \mathrm{~Pb}$ & $1 \sigma$ & ${ }^{207} \mathrm{~Pb} /{ }^{235} \mathrm{U}$ & $1 \sigma$ & ${ }^{206} \mathrm{~Pb} /{ }^{238} \mathrm{U}$ & $1 \sigma$ & ${ }^{207} \mathrm{~Pb} /{ }^{235} \mathrm{U}$ age $(\mathrm{Ma})$ & ${ }^{206} \mathrm{~Pb} /{ }^{238} \mathrm{U}$ age $(\mathrm{Ma})$ \\
\hline CB-1 & 109 & 83 & 1.31 & 0.06559 & 0.00113 & 1.16638 & 0.02052 & 0.12899 & 0.00162 & $785 \pm 10$ & $782 \pm 9$ \\
\hline CB-2 & 324 & 457 & 0.71 & 0.05033 & 0.00133 & 0.23458 & 0.00608 & 0.03381 & 0.00045 & $214 \pm 5$ & $214 \pm 3$ \\
\hline CB-3 & 377 & 513 & 0.74 & 0.04882 & 0.00081 & 0.22652 & 0.00388 & 0.03366 & 0.00041 & $207 \pm 3$ & $213 \pm 3$ \\
\hline CB-4 & 62 & 241 & 0.26 & 0.05166 & 0.00147 & 0.23412 & 0.0066 & 0.03287 & 0.00049 & $214 \pm 5$ & $208 \pm 3$ \\
\hline CB-5 & 22 & 215 & 0.1 & 0.05092 & 0.00156 & 0.24191 & 0.00728 & 0.03446 & 0.0005 & $220 \pm 6$ & $218 \pm 3$ \\
\hline CB-6 & 320 & 181 & 1.77 & 0.06544 & 0.00161 & 1.11588 & 0.02661 & 0.12371 & 0.00164 & $761 \pm 13$ & $752 \pm 9$ \\
\hline CB-8 & 495 & 211 & 2.35 & 0.06524 & 0.00232 & 1.11759 & 0.03869 & 0.12429 & 0.0021 & $762 \pm 19$ & $755 \pm 12$ \\
\hline CB-9 & 379 & 221 & 1.72 & 0.06724 & 0.00112 & 1.14475 & 0.01981 & 0.12349 & 0.00158 & $775 \pm 9$ & $751 \pm 9$ \\
\hline CB-10 & 150 & 420 & 0.36 & 0.0505 & 0.00092 & 0.22564 & 0.00423 & 0.03241 & 0.00042 & $207 \pm 4$ & $206 \pm 3$ \\
\hline CB-11 & 1649 & 824 & 2 & 0.05033 & 0.00142 & 0.22964 & 0.00647 & 0.03309 & 0.00051 & $210 \pm 5$ & $210 \pm 3$ \\
\hline CB-12 & 97 & 470 & 0.21 & 0.04925 & 0.00083 & 0.22875 & 0.004 & 0.03368 & 0.00042 & $209 \pm 3$ & $214 \pm 3$ \\
\hline CB-13 & 35 & 142 & 0.24 & 0.04879 & 0.00195 & 0.22504 & 0.00876 & 0.03346 & 0.00054 & $206 \pm 7$ & $212 \pm 3$ \\
\hline CB-14 & 66 & 389 & 0.17 & 0.04804 & 0.00086 & 0.22646 & 0.00417 & 0.03419 & 0.00044 & $207 \pm 3$ & $217 \pm 3$ \\
\hline CB-16 & 100 & 323 & 0.31 & 0.04798 & 0.00105 & 0.22414 & 0.0049 & 0.03388 & 0.00045 & $205 \pm 4$ & $215 \pm 3$ \\
\hline CB-17 & 396 & 595 & 0.67 & 0.05065 & 0.00086 & 0.23366 & 0.00406 & 0.03346 & 0.00041 & $213 \pm 3$ & $212 \pm 3$ \\
\hline HZG-1 & 80 & 181 & 0.44 & 0.05077 & 0.00119 & 0.2396 & 0.00553 & 0.03423 & 0.00043 & $218 \pm 5$ & $217 \pm 3$ \\
\hline HZG-2 & 361 & 1351 & 0.27 & 0.05195 & 0.00233 & 0.23872 & 0.01032 & 0.03333 & 0.0004 & $217 \pm 8$ & $211 \pm 2$ \\
\hline HZG-3 & 166 & 222 & 0.75 & 0.05326 & 0.00315 & 0.24543 & 0.01405 & 0.03344 & 0.00074 & $223 \pm 11$ & $212 \pm 5$ \\
\hline HZG-4 & 221 & 318 & 0.69 & 0.05101 & 0.00112 & 0.23669 & 0.00526 & 0.03365 & 0.00045 & $216 \pm 4$ & $213 \pm 3$ \\
\hline HZG-5 & 108 & 132 & 0.82 & 0.05312 & 0.00181 & 0.24925 & 0.00833 & 0.03403 & 0.00052 & $226 \pm 7$ & $216 \pm 3$ \\
\hline HZG-6 & 430 & 504 & 0.85 & 0.05092 & 0.00143 & 0.23591 & 0.00661 & 0.0336 & 0.0005 & $215 \pm 5$ & $213 \pm 3$ \\
\hline HZG-7 & 68 & 114 & 0.6 & 0.05279 & 0.00215 & 0.24568 & 0.00968 & 0.03376 & 0.00054 & $223 \pm 8$ & $214 \pm 3$ \\
\hline HZG-8 & 105 & 120 & 0.88 & 0.05124 & 0.00141 & 0.23827 & 0.00648 & 0.03373 & 0.00046 & $217 \pm 5$ & $214 \pm 3$ \\
\hline HZG-9 & 109 & 129 & 0.85 & 0.05114 & 0.00149 & 0.23831 & 0.00681 & 0.0338 & 0.00046 & $217 \pm 6$ & $214 \pm 3$ \\
\hline HZG-10 & 130 & 145 & 0.9 & 0.05365 & 0.00185 & 0.25015 & 0.00843 & 0.03382 & 0.00053 & $227 \pm 7$ & $214 \pm 3$ \\
\hline HZG-11 & 566 & 770 & 0.73 & 0.05151 & 0.00086 & 0.24158 & 0.00414 & 0.03402 & 0.00042 & $220 \pm 3$ & $216 \pm 3$ \\
\hline HZG-14 & 129 & 166 & 0.78 & 0.05085 & 0.00206 & 0.23208 & 0.00909 & 0.0331 & 0.00052 & $212 \pm 7$ & $210 \pm 3$ \\
\hline HZG-15 & 150 & 158 & 0.95 & 0.05067 & 0.00208 & 0.23933 & 0.0096 & 0.03426 & 0.00058 & $218 \pm 8$ & $217 \pm 4$ \\
\hline HZG-16 & 188 & 162 & 1.16 & 0.052 & 0.0019 & 0.24165 & 0.00867 & 0.03371 & 0.00055 & $220 \pm 7$ & $214 \pm 3$ \\
\hline HZG-17 & 179 & 238 & 0.75 & 0.05048 & 0.00135 & 0.23886 & 0.00643 & 0.03432 & 0.0005 & $217 \pm 5$ & $218 \pm 3$ \\
\hline HZG-18 & 248 & 893 & 0.28 & 0.05443 & 0.00128 & 0.25569 & 0.00626 & 0.03408 & 0.00052 & $231 \pm 5$ & $216 \pm 3$ \\
\hline HZG-19 & 110 & 144 & 0.76 & 0.05036 & 0.00174 & 0.23866 & 0.00807 & 0.03437 & 0.00052 & $217 \pm 7$ & $218 \pm 3$ \\
\hline HZG-20 & 166 & 175 & 0.95 & 0.0512 & 0.00214 & 0.24141 & 0.00985 & 0.0342 & 0.00058 & $220 \pm 8$ & $217 \pm 4$ \\
\hline HZG-21 & 133 & 155 & 0.86 & 0.05124 & 0.00197 & 0.23094 & 0.00859 & 0.03269 & 0.0005 & $211 \pm 7$ & $207 \pm 3$ \\
\hline HZG-22 & 166 & 254 & 0.65 & 0.05117 & 0.00131 & 0.24483 & 0.00624 & 0.0347 & 0.00048 & $222 \pm 5$ & $220 \pm 3$ \\
\hline HZG-23 & 80 & 110 & 0.73 & 0.05049 & 0.00211 & 0.24358 & 0.00999 & 0.035 & 0.00058 & $221 \pm 8$ & $222 \pm 4$ \\
\hline HZG-24 & 179 & 215 & 0.83 & 0.05032 & 0.00206 & 0.22873 & 0.00911 & 0.03299 & 0.00056 & $209 \pm 8$ & $209 \pm 3$ \\
\hline HZG-25 & 716 & 484 & 1.48 & 0.05197 & 0.00136 & 0.23061 & 0.00594 & 0.03219 & 0.00045 & $211 \pm 5$ & $204 \pm 3$ \\
\hline HZG-26 & 202 & 199 & 1.01 & 0.05038 & 0.00124 & 0.23534 & 0.00579 & 0.03389 & 0.00045 & $215 \pm 5$ & $215 \pm 3$ \\
\hline
\end{tabular}




\begin{tabular}{cccccccccccc}
\hline Sample & $\mathrm{Th}\left(\mu \mathrm{g} \mathrm{g}{ }^{-1}\right)$ & $\mathrm{U}\left(\mu \mathrm{g} \mathrm{g}^{-1}\right)$ & $\mathrm{Th} / \mathrm{U}$ & ${ }^{207} \mathrm{~Pb} /{ }^{206} \mathrm{~Pb}$ & $1 \sigma$ & ${ }^{207} \mathrm{~Pb} /{ }^{235} \mathrm{U}$ & $1 \sigma$ & ${ }^{206} \mathrm{~Pb} /{ }^{238} \mathrm{U}$ & $1 \sigma$ & ${ }^{207} \mathrm{~Pb} /{ }^{235} \mathrm{U} \mathrm{age}(\mathrm{Ma})$ & ${ }^{206} \mathrm{~Pb} /{ }^{238} \mathrm{U} \mathrm{age}(\mathrm{Ma})$ \\
\hline HZG-27 & 285 & 290 & 0.98 & 0.05135 & 0.0011 & 0.23981 & 0.00518 & 0.03388 & 0.00044 & $218 \pm 4$ & $215 \pm 3$ \\
HZG-28 & 626 & 471 & 1.33 & 0.05117 & 0.00127 & 0.24016 & 0.00594 & 0.03406 & 0.00047 & $219 \pm 5$ & $216 \pm 3$ \\
HZG-29 & 146 & 156 & 0.94 & 0.05417 & 0.00155 & 0.25127 & 0.00713 & 0.03365 & 0.00048 & $228 \pm 6$ & $213 \pm 3$ \\
HZG-30 & 93 & 119 & 0.78 & 0.05061 & 0.00226 & 0.23269 & 0.01011 & 0.03336 & 0.00057 & $212 \pm 8$ & $212 \pm 4$ \\
HZG-31 & 144 & 164 & 0.88 & 0.05057 & 0.00158 & 0.23314 & 0.00719 & 0.03344 & 0.00048 & $213 \pm 6$ & $212 \pm 3$ \\
HZG-32 & 183 & 295 & 0.62 & 0.05157 & 0.00124 & 0.24881 & 0.00604 & 0.035 & 0.00049 & $226 \pm 5$ & $22 \pm \pm 3$ \\
HZG-33 & 656 & 1681 & 0.39 & 0.05175 & 0.00106 & 0.23431 & 0.00487 & 0.03284 & 0.00043 & $214 \pm 4$ & $208 \pm 3$ \\
\hline
\end{tabular}

a) HZG 1-19 are zircons from central phase and HZG 20-33 from marginal phase of HZG intrusion.

have a wide range of $U$ (70 to $1681 \mathrm{ppm})$ and Th (22 to $1649 \mathrm{ppm}$ ), with high $\mathrm{Th} / \mathrm{U}$ ratios of 0.1 to 2.35 (Table 2), indicating their magmatic origins [38].

For the central phase of the HZG intrusion, all grains plot on or near the concordia curve and yield $a{ }^{206} \mathrm{~Pb} /{ }^{238} \mathrm{U}$

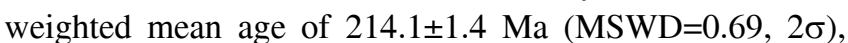
which is considered the best estimate of crystallization age for the central phase of the HZG intrusion (Figure 4a). For the marginal phase of the HZG intrusion, almost all grains plot on or near the concordia curve and yield a ${ }^{206} \mathrm{~Pb} /{ }^{238} \mathrm{U}$ weighted mean age of 213.4 $\pm 3.2 \mathrm{Ma}(\mathrm{MSWD}=3.1,2 \sigma)$, which is considered the best estimate of crystallization age for the marginal phase of the HZG intrusion (Figure 4b). The consistent zircon $\mathrm{U}-\mathrm{Pb}$ ages for the central and marginal phases of the HZG intrusion suggest they formed simultaneously.

For the CB intrusion, 11 grains were on or near the concordia curve and yield a ${ }^{206} \mathrm{~Pb} /{ }^{238} \mathrm{U}$ weighted mean age of $212.6 \pm 2.4 \mathrm{Ma}(\mathrm{MSWD}=1.5,2 \sigma)$, which is considered the best estimate for crystallization age of the $\mathrm{CB}$ intrusion (Figure 5). There also are some inherited zircons from the CB intrusion, which yield a weighted mean age of $757 \pm 14$ Ma for 6 analyses (MSWD=2, 2 $\sigma$ ).

\subsection{Major and trace elements}

Major and trace element compositions of the HZG and CB intrusions are given in Table 3. Samples from the central phase of the HZG intrusion are poor in $\mathrm{SiO}_{2}(62.44$ to 68.38 wt.\%), rich in $\mathrm{MgO}$ (1.59 to 3.70 wt. $\%, \mathrm{Mg}^{\#}=0.55$ to 0.57 ),

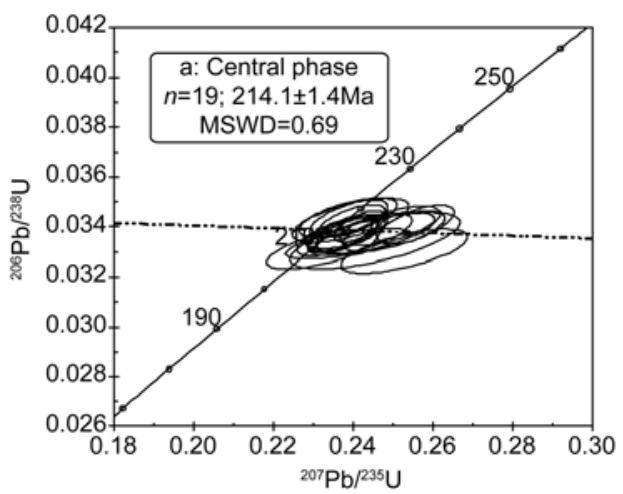

and are metaluminous with 15.79 to 16.22 wt. $\% \mathrm{Al}_{2} \mathrm{O}_{3}$ and $\mathrm{A} / \mathrm{CNK}$ of 0.90 to 0.97 . They are high-K calc-alkaline with low alkalis $\left(\mathrm{Na}_{2} \mathrm{O}+\mathrm{K}_{2} \mathrm{O}=6.39\right.$ to 7.67 wt. $\%, \mathrm{~K}_{2} \mathrm{O} / \mathrm{Na}_{2} \mathrm{O}=$ 0.69 to $0.93, \mathrm{AKI}=0.56$ to 0.67 ), and $\mathrm{CaO}$ of 3.11 to 4.95 wt.\% (Figure 6). They have a range of normalized $\mathrm{Fe}_{2} \mathrm{O}_{3}{ }^{\mathrm{T}}$ from 2.62 to 5.19 , with Fe numbers from 0.56 to 0.60 . Samples from the marginal phase of the HZG intrusion are more felsic than the central phase, and thus have high $\mathrm{SiO}_{2}(72.17$ to 73.32 wt.\%), low $\mathrm{MgO}$ (0.63 to 0.73 wt. $\%, \mathrm{Mg}^{\#}=0.48$ to 0.51 ), a range of $\mathrm{Fe}_{2} \mathrm{O}_{3}^{\mathrm{T}}$ contents (1.30 to $1.45 \mathrm{wt} . \%$, $\mathrm{Fe}$ number $=0.63$ to 0.66 ), and are peraluminous with 14.58 to 14.66 wt. $\% \mathrm{Al}_{2} \mathrm{O}_{3}$ and $\mathrm{A} / \mathrm{CNK}$ of 1.09 to 1.17 . They are high- $\mathrm{K}$ calc-alkaline with high alkalis $\left(\mathrm{Na}_{2} \mathrm{O}+\mathrm{K}_{2} \mathrm{O}=7.49\right.$ to 8.17 wt. $\%, \mathrm{~K}_{2} \mathrm{O} / \mathrm{Na}_{2} \mathrm{O}=1.0$ to 1.04 , $\mathrm{AKI}=0.70$ to 0.76 ), and low $\mathrm{CaO}$ from 1.08 to $1.41 \mathrm{wt}$ \% (Figure 6 ).

The central and marginal phases of the HZG intrusion show similar patterns of rare earth element (REE) distribution (Figure 7a) with weak Eu anomalies $\left(\mathrm{Eu} / \mathrm{Eu}^{*}=0.82\right.$ to 0.87 and 0.85 to 1.08$)$, and flat HREE patterns $\left[(\mathrm{Gd} / \mathrm{Yb})_{\mathrm{N}}\right.$ 1.89 to 2.10 and 1.36 to 1.98 ]. They have higher REE contents of 84.8 to $114 \mathrm{ppm}$ and 40.5 to $84.4 \mathrm{ppm}$, and lower $(\mathrm{La} / \mathrm{Yb})_{\mathrm{N}}$ ratios of 11.57 to 11.82 and 6.62 to 22.6. PM-normalized patterns of trace element distribution (Figure $7 \mathrm{~b}$ ) indicate they are both rich in large ion lithophile elements (LILE), depleted in high field strength elements (HFSE), and show spikes in $\mathrm{Ba}, \mathrm{Sr}$ and $\mathrm{K}$ but troughs in $\mathrm{Nb}$, Ta, $\mathrm{P}$ and Ti.

Samples of the CB intrusion have higher $\mathrm{SiO}_{2}(73.91 \%$ to $74.66 \mathrm{wt} \%$ ) than the other Triassic granites in the Qinling orogen [23], and are peraluminous with $13.78 \%$ to

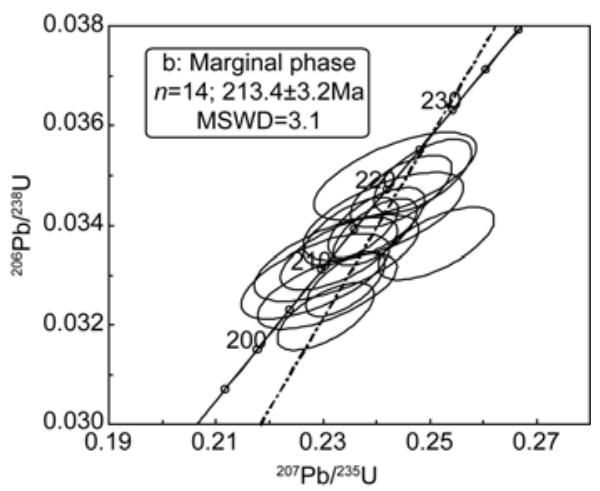

Figure 4 LA-ICP-MS zircon U-Pb concordia diagram for central phase (a) and marginal phase (b) of HZG intrusion. 


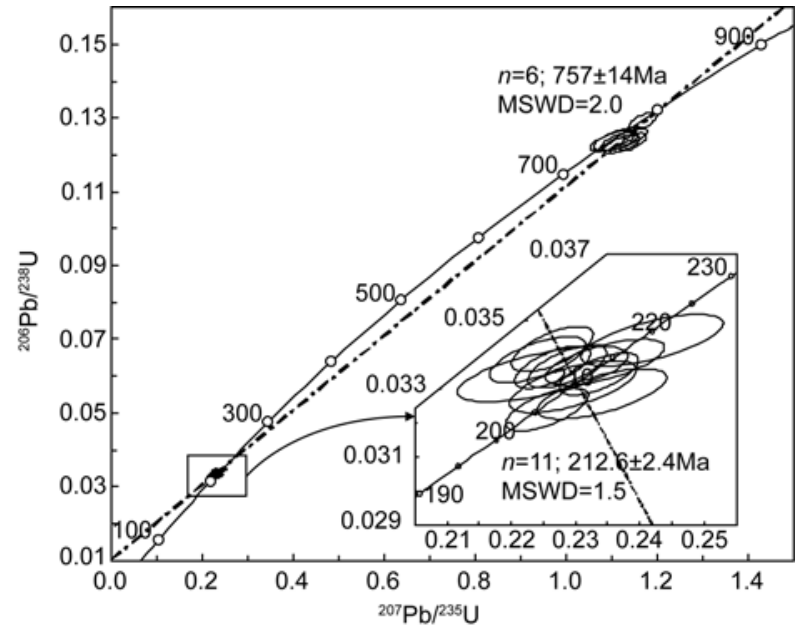

Figure 5 LA-ICP-MS zircon U-Pb concordia diagram for the CB intrusion.
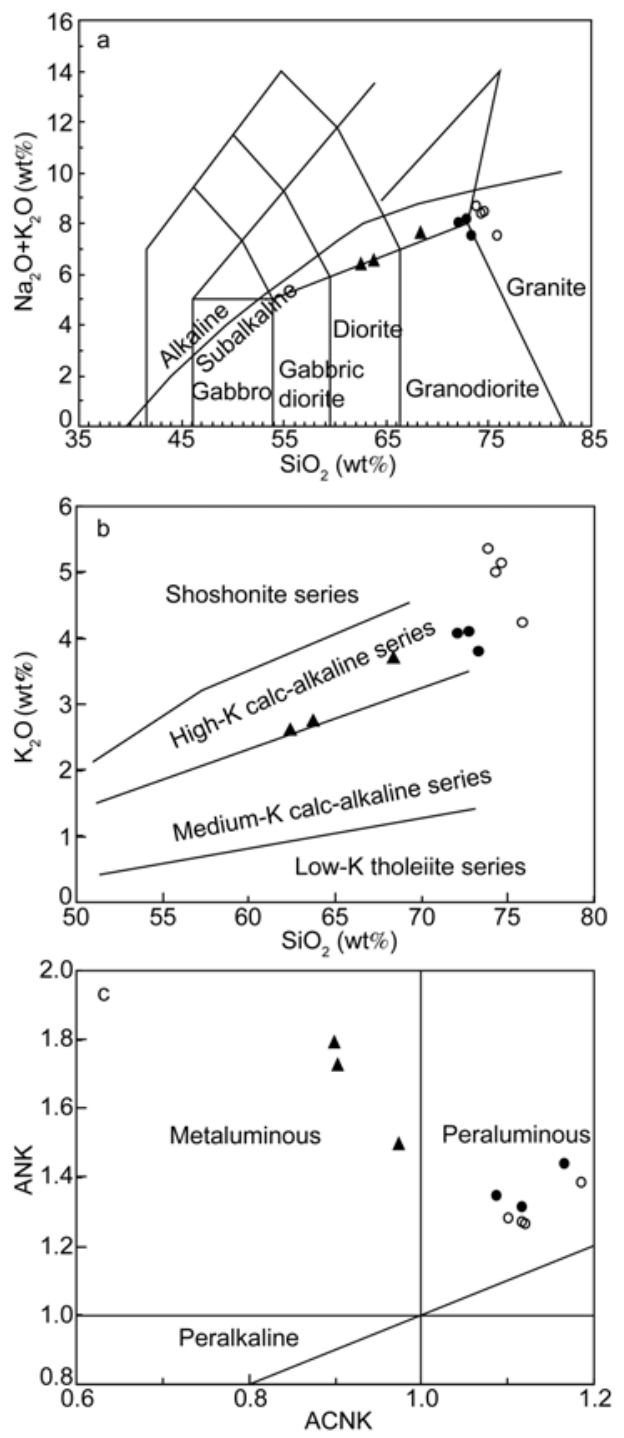

Figure 6 Plots of (a) $\mathrm{Na}_{2} \mathrm{O}+\mathrm{K}_{2} \mathrm{O}$ vs. $\mathrm{SiO}_{2}$; (b) $\mathrm{SiO}_{2}$ vs. $\mathrm{K}_{2} \mathrm{O}$; (c) A/NK vs. $\mathrm{A} / \mathrm{CNK}$ for the HZG and CB intrusions. $\boldsymbol{\Delta}$, Central phase of HZG intrusion;
14.24 wt. $\% \mathrm{Al}_{2} \mathrm{O}_{3}$ and $\mathrm{A} / \mathrm{CNK}$ of 1.10 to 1.19 . They are high- $\mathrm{K}$ calc-alkaline with high $\mathrm{K}_{2} \mathrm{O}\left(\mathrm{Na}_{2} \mathrm{O} / \mathrm{K}_{2} \mathrm{O}=0.62\right.$ to $0.77, \mathrm{AKI}=0.72$ to 0.79 ) (Figure 6) and an Fe number range of 0.84 to 0.85 .

The CB granites show different REE patterns (Figure 7c) with prominent, negative $\mathrm{Eu}$ anomalies, and higher REE contents of 152 to $214 \mathrm{ppm}$ and $(\mathrm{La} / \mathrm{Yb})_{\mathrm{N}}$ ratios of 24.9 to 28.5. PM-normalized trace element patterns (Figure 7d) show the similar features for the $\mathrm{CB}$ and HZG intrusions, and both are rich in LILE and depleted in HFSE, although there are some differences. Samples of the CB granite show spikes in Th and $\mathrm{U}$ but troughs in $\mathrm{P}$ and Ti. The spikes in $\mathrm{Rb}, \mathrm{Nb}$ and $\mathrm{Ta}$ and troughs in $\mathrm{Eu}, \mathrm{Ba}$ and $\mathrm{Sr}$ are more pronounced than in the HZG intrusion.

\section{Discussion}

\subsection{Information from inherited zircon}

Inherited zircons in granites can provide information on their magma sources $[5,7,40]$. Neoproterozoic rift magmatism is an important index of the continental crust in the South China Block $[7,41]$. There are middle Neoproterozoic magmatic events in the South China Block. Magmatism of 830-740 Ma have been widely documented along the Yangtze margins [42-44] and its interior region [45]. In comparison, 780-740 Ma igneous suites, including diorite/ gabbro dykes [43,44], an adakitic intrusive complex [46] and gabbroic plutons [47] have been recognized in the Kangdian Rift, on the western margin of the Yangtze Block. Furthermore, a bimodal eclogite-gneiss suite has been identified in the Dabie-Sulu orogenic belt $[7,48,50]$. The two groups of zircon U-Pb ages at 830-800 and 780-740 Ma correspond to two periods of extensional magmatism, respectively, due to tectonic collapse of Early Neoproterzoic arc-continent collision orogen [51] and continental rifting in response to breakup of the Rodinia supercontinent [52]. There were no contemporaneous magmatic events in the North China Block [41,50]. The inherited zircons in the CB granite have $\mathrm{U}-\mathrm{Pb}$ ages of $757 \pm 14 \mathrm{Ma}$, indicating that its source is a product of mid-Neoproterozoic rift magmatism along the northern margin of the South China Block [51,52].

\subsection{Origin of the monzogranite}

The HZG and CB intrusions are both high-K calc-alkaline, while the HZG intrusion varies in rock types from diorite to granite, composed mainly of plagioclase, quartz, biotite and amphibole with minor zircon and apatite. For the HZG granite, there are linear correlations between $\mathrm{SiO}_{2}$ contents and the other major oxides. In particular, as $\mathrm{SiO}_{2}$ contents increase, the alkali contents increase, and the other oxide contents decrease. These correlations indicate they are the evolutional products of cognate magma. High $\mathrm{Na}_{2} \mathrm{O} / \mathrm{K}_{2} \mathrm{O}$, 
Table 3 Major (\%) and trace element $\left(\mu \mathrm{g} \mathrm{g}^{-1}\right)$ analyses of the HZG and CB intrusions ${ }^{\mathrm{a})}$

\begin{tabular}{|c|c|c|c|c|c|c|c|c|c|c|}
\hline & $\mathrm{H}-03$ & $\mathrm{H}-05$ & H-06 & $\mathrm{H}-07$ & $\mathrm{H}-08$ & H-09 & B-01 & B-02 & B-03 & B-04 \\
\hline $\mathrm{SiO}_{2}$ & 63.77 & 62.44 & 68.38 & 72.17 & 72.83 & 73.32 & 74.66 & 75.85 & 74.32 & 73.91 \\
\hline $\mathrm{TiO}_{2}$ & 0.60 & 0.65 & 0.35 & 0.18 & 0.17 & 0.17 & 0.15 & 0.14 & 0.17 & 0.15 \\
\hline $\mathrm{Al}_{2} \mathrm{O}_{3}$ & 15.94 & 16.22 & 15.79 & 14.58 & 14.66 & 14.66 & 14.00 & 13.78 & 13.99 & 14.24 \\
\hline $\mathrm{TFe}_{2} \mathrm{O}_{3}$ & 4.79 & 5.19 & 2.62 & 1.38 & 1.30 & 1.45 & 1.29 & 1.22 & 1.34 & 1.31 \\
\hline $\mathrm{MnO}$ & 0.07 & 0.08 & 0.04 & 0.03 & 0.03 & 0.03 & 0.04 & 0.04 & 0.05 & 0.04 \\
\hline $\mathrm{MgO}$ & 3.16 & 3.70 & 1.59 & 0.73 & 0.63 & 0.68 & 0.22 & 0.20 & 0.21 & 0.23 \\
\hline $\mathrm{Na}_{2} \mathrm{O}$ & 3.79 & 3.77 & 3.97 & 3.90 & 4.08 & 3.71 & 3.33 & 3.26 & 3.35 & 3.33 \\
\hline $\mathrm{K}_{2} \mathrm{O}$ & 2.76 & 2.62 & 3.70 & 4.07 & 4.09 & 3.78 & 5.13 & 4.24 & 4.99 & 5.34 \\
\hline $\mathrm{P}_{2} \mathrm{O}_{5}$ & 0.16 & 0.18 & 0.12 & 0.08 & 0.08 & 0.08 & 0.08 & 0.09 & 0.09 & 0.09 \\
\hline LOI & 0.15 & 0.18 & 0.27 & 1.39 & 1.03 & 0.78 & 0.34 & 0.25 & 0.25 & 0.54 \\
\hline SUM & 99.81 & 99.98 & 99.94 & 99.92 & 99.98 & 99.96 & 100.06 & 99.98 & 99.73 & 99.96 \\
\hline ANK & 1.73 & 1.79 & 1.50 & 1.35 & 1.31 & 1.44 & 1.27 & 1.38 & 1.28 & 1.26 \\
\hline ACNK & 0.90 & 0.90 & 0.97 & 1.09 & 1.12 & 1.17 & 1.12 & 1.19 & 1.10 & 1.12 \\
\hline $\mathrm{La}$ & 25.6 & 25.0 & 19.5 & 24.0 & 8.4 & 18.6 & 38.2 & 40.6 & 55.5 & 47.5 \\
\hline $\mathrm{Ce}$ & 41.5 & 37.4 & 34.2 & 35.0 & 16.4 & 29.2 & 69.9 & 68.9 & 98.7 & 87.6 \\
\hline $\operatorname{Pr}$ & 5.85 & 5.20 & 4.03 & 3.97 & 1.73 & 2.91 & 7.29 & 7.43 & 9.85 & 8.69 \\
\hline $\mathrm{Nd}$ & 23.1 & 21.0 & 15.3 & 13.4 & 6.6 & 10.3 & 23.8 & 25.0 & 32.6 & 29.2 \\
\hline $\mathrm{Sm}$ & 4.39 & 3.97 & 2.87 & 2.10 & 1.35 & 1.62 & 3.80 & 4.06 & 5.17 & 4.37 \\
\hline $\mathrm{Eu}$ & 1.20 & 1.15 & 0.80 & 0.59 & 0.48 & 0.59 & 0.46 & 0.48 & 0.56 & 0.54 \\
\hline $\mathrm{Gd}$ & 3.91 & 3.55 & 2.57 & 1.83 & 1.49 & 1.47 & 3.14 & 3.16 & 4.34 & 3.65 \\
\hline $\mathrm{Tb}$ & 0.58 & 0.52 & 0.40 & 0.27 & 0.26 & 0.21 & 0.43 & 0.43 & 0.57 & 0.49 \\
\hline Dy & 3.11 & 2.79 & 2.07 & 1.32 & 1.51 & 1.15 & 2.14 & 2.16 & 2.90 & 2.51 \\
\hline Ho & 0.58 & 0.51 & 0.38 & 0.25 & 0.29 & 0.21 & 0.37 & 0.37 & 0.49 & 0.44 \\
\hline $\mathrm{Er}$ & 1.68 & 1.48 & 1.13 & 0.72 & 0.86 & 0.66 & 1.06 & 1.09 & 1.43 & 1.32 \\
\hline $\mathrm{Tm}$ & 0.24 & 0.21 & 0.17 & 0.11 & 0.13 & 0.09 & 0.16 & 0.16 & 0.21 & 0.20 \\
\hline $\mathrm{Yb}$ & 1.54 & 1.36 & 1.09 & 0.74 & 0.88 & 0.67 & 1.07 & 1.05 & 1.35 & 1.32 \\
\hline$\delta \mathrm{Eu}$ & 0.87 & 0.64 & 0.65 & 0.89 & 1.03 & 1.15 & 0.40 & 0.40 & 0.35 & 0.40 \\
\hline$\Sigma \mathrm{REE}$ & 114 & 104 & 84.8 & 84.4 & 40.5 & 67.8 & 152 & 155 & 214 & 188 \\
\hline $\mathrm{Sc}$ & 17.2 & 14.5 & 7.51 & 3.35 & 2.91 & 3.12 & 2.46 & 1.57 & 2.70 & 2.25 \\
\hline $\mathrm{Cr}$ & 100 & 113 & 58.6 & 33.0 & 24.8 & 30.6 & 13.9 & 12.6 & 13.3 & 5.73 \\
\hline $\mathrm{Ni}$ & 32.2 & 35.5 & 20.1 & 12.8 & 5.13 & 6.71 & 2.63 & 2.54 & 1.75 & 2.23 \\
\hline $\mathrm{Rb}$ & 82.2 & 57.5 & 70.3 & 106 & 98.5 & 103 & 302 & 291 & 313 & 302 \\
\hline $\mathrm{Ba}$ & 1201 & 1120 & 1054 & 1120 & 917 & 1373 & 441 & 472 & 494 & 522 \\
\hline Th & 7.13 & 6.34 & 23.5 & 9.78 & 10.3 & 9.24 & 38.7 & 37.7 & 54.2 & 46.9 \\
\hline $\mathrm{U}$ & 2.85 & 1.59 & 2.94 & 1.41 & 2.78 & 3.16 & 4.22 & 2.61 & 5.05 & 7.84 \\
\hline $\mathrm{Nb}$ & 8.14 & 7.68 & 8.63 & 7.21 & 11.6 & 7.46 & 19.4 & 17.5 & 19.2 & 17.3 \\
\hline $\mathrm{Ta}$ & 0.72 & 0.65 & 1.04 & 1.08 & 1.86 & 0.95 & 2.40 & 1.99 & 2.33 & 2.09 \\
\hline $\mathrm{Pb}$ & 85.2 & 69.1 & 103 & 67.9 & 94.0 & 109 & 88.2 & 61.7 & 70.1 & 135 \\
\hline $\mathrm{Sr}$ & 589 & 557 & 450 & 322 & 246 & 379 & 124 & 103 & 139 & 136 \\
\hline $\mathrm{Zr}$ & 158 & 142 & 109 & 73.9 & 84.4 & 80.7 & 114 & 116 & 124 & 127 \\
\hline Hf & 4.66 & 4.14 & 3.41 & 2.36 & 2.99 & 2.44 & 3.91 & 3.99 & 4.21 & 4.29 \\
\hline $\mathrm{Y}$ & 16.2 & 14.6 & 11.2 & 7.77 & 7.96 & 6.47 & 10.6 & 11.2 & 14.6 & 13.2 \\
\hline
\end{tabular}

a) $\mathrm{H}-03,05,06$ are samples from the central phase and $\mathrm{H}-07$ to 09 from the marginal phase of the $\mathrm{HZG}$ intrusion, $\mathrm{B}-01$ to 04 from the $\mathrm{CB}$ intrusion.

$\mathrm{Ca}$ and $\mathrm{Sr}$ contents for the HZG intrusion are similar to those for I-type granites. The HZG intrusion shows spikes in $\mathrm{Ba}, \mathrm{Sr}$ and $\mathrm{K}$ but troughs in $\mathrm{Nb}$, Ta, Ti and $\mathrm{P}$, and is rich in LREE and depleted in HREE. These are common features of arc-type igneous rocks. In contrast, the CB granite is rich in K-feldspar, with some muscovite, which is similar to muscovite-bearing peraluminous granitoids [53]. Muscovite-bearing peraluminous granitoids are rich in $\mathrm{Si}$ and $\mathrm{K}$, poor in $\mathrm{Na}, \mathrm{Al}, \mathrm{Mg}$ and $\mathrm{Ca}$, and display relative enrichment in HFSE such as $\mathrm{Nb}, \mathrm{Ga}$ and $\mathrm{Y}$. The $\mathrm{CB}$ granite is high in 

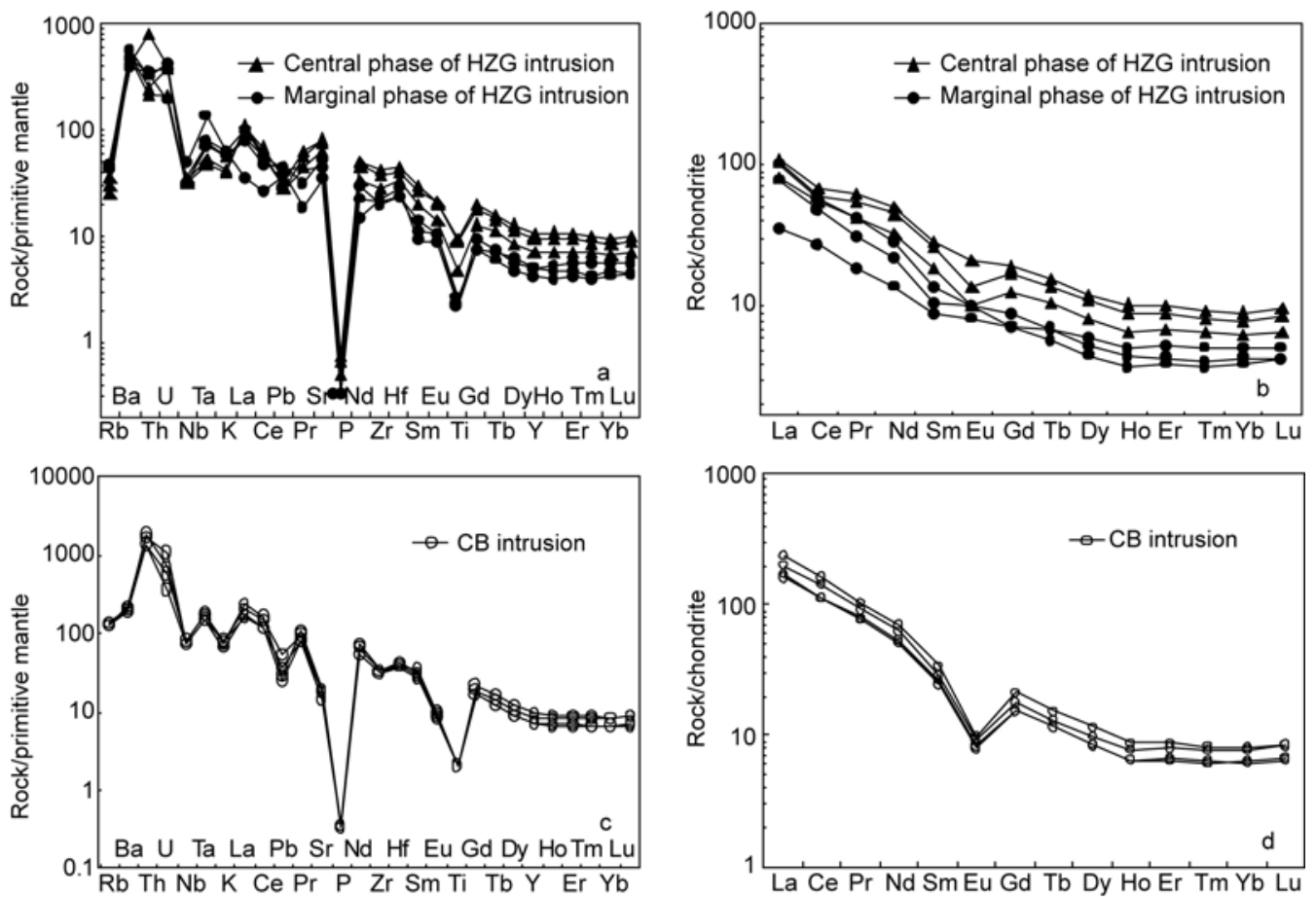

Figure 7 Chondrite normalized REE patterns for the HZG (a) and CB (c) intrusions; primitive mantle (PM) normalized trace element patterns of the HZG (b) and CB (d) intrusions. Chondrite values and PM values from McDonough and Sun [39].

$\mathrm{Fe}^{\mathrm{T}} / \mathrm{Mg}$, and displays right inclination with a prominent negative $\mathrm{Eu}$ anomaly in its chondrite-normalized REE patterns, and shows troughs of $\mathrm{Sr}, \mathrm{Ba}, \mathrm{Ti}$ and $\mathrm{P}$ in its primitive mantle (PM) normalized trace element patterns. Compared to the HZG intrusion, the $\mathrm{CB}$ granite is depleted in $\mathrm{Eu}, \mathrm{Ba}$ and $\mathrm{Sr}$, which suggests it underwent fractionation of plagioclase. Thus the CB is the strong differentiation granite and thus a product of highly evolved magma, and shows features of post-collision A-type granites [54]. This suggests that the Qinling orogen at this time was evolved into an extensional period after the main collision [9].

Mafic enclaves are ubiquitous in the Triassic granites in the Qinling orogen. Their mineral compositions and textures imply that they are associated with magma mixing, and zircon Lu-Hf isotopic compositions show that they were derived from reworking of Neoproterozoic juvenile subcontinental lithosphere mantle (SCLM) [30,34]. Mafic enclaves in the central phase of the HZG intrusion show similar mineral compositions and textures, which implies they have the same origin. Thus the HZG intrusion could be formed by magma mixing. The central phase of the HZG intrusion is high in $\mathrm{Mg \#}, \mathrm{Cr}$ (58.6-113 ppm) and $\mathrm{Ni}$ (20.1-35.5), also suggesting possible addition of mafic magma. The high $\mathrm{Sr}$ concentrations (246 to $589 \mathrm{ppm}$ ) imply a plagioclase-rich (i.e. intermediate) source; and the concave-upward REE patterns without significant $\mathrm{Eu}$ anomalies suggest the presence of amphibole restite [55]. On the basis of the above arguments, the HZG intrusion was likely originated from partial melting of a source rich in plagioclase, whereas the
$\mathrm{CB}$ granite is a product of highly evolved magmas which experienced fractionation of plagioclase.

\subsection{Geodynamic implications}

The Late Triassic granites are widespread in the Qinling orogen (Table 1). There are also the same episode of alkali granites in the Dabie-Sulu orogenic belt $[56,57]$, which also show the similar patterns of arc-like REE and trace element distribution [5,58-60]. The Neoproterozoic age of inherited zircons in the CB granite indicates that its source is a product of mid-Neoproterozoic rift magmatism along the northern margin of the South China Block. The similar origin has been inferred for the protoliths of UHP metaigneous rocks in the Dabie-Sulu orogenic belt $[7,49,50]$. These similarities in geochemistry and geochronology for the Late Triassic granites between Qinling and Dabie-Sulu imply that they have the same origin. They corresponds to syn-exhumation magmatism [48] and thus are ascrible to extensional anatexis of the exhuming continental slab itself $[5,6]$.

In summary, petrogenesis of the HZG and CB intrusions can be postulated as follows. In the Neoproterozoic, growth and reworking of juvenile continental lithosphere occurred during breakup of Rodinia supercontinent along the northern margin of the South China Block. In the Paleozoic, arc magmatism was initiated by northward subduction of the north-eastern part of the Paleo-Tethys oceanic crust $[3,14,61,62]$. Then the continental collision between the South and North China Blocks occurred in the Triassic, 
resulting in the formation of thickened crust along the Mianlue suture zone and the formation of UHP metamorphic rocks in the Dabie-Sulu orogenc belt [6]. Subsequently slab break-off occurred at shallow depth $[8,63]$, the subduction of continental crust was terminated and exhumation of deeply subducted continental lithosphere occurred. At this time there was a thermal pulse associated with the slab break-off due to upwelling of the asthenospheric mantle along the Mianlue suture. This upwelling would trigger partial melting of the orogenic crust that has the tectonic affinity of the South China Block. The crustal materials of different compositions would be involved in the extensional anatexis, giving rise to the HZG and $\mathrm{CB}$ granites, respectively.

\section{Conclusions}

The zircon U-Pb ages of the HZG $(214 \pm 1 \mathrm{Ma}$ for the central phase, $213 \pm 3$ Ma for the marginal phase) and CB intrusions $(213 \pm 2 \mathrm{Ma})$ are identical to the other Triassic granites in the Qinling orogen as well as alkali granites in the Dabie-Sulu orogenic belt. They both show similar arc-type patterns of REE and trace element distribution. The CB is a strong differentiation granite and shows the features of post-collision A-type granites, and its occurrence suggests that the Qinling orogen was evolved into an extensional period after the main collision. Inherited zircons in the $\mathrm{CB}$ intrusion have $\mathrm{U}-\mathrm{Pb}$ ages of $757 \pm 14 \mathrm{Ma}$, suggesting that its source is a product of mid-Neoproterozoic rift magmatism during breakup of the Rodinia supercontinent along the northern margin of the South China Block. The HZG and CB intrusions were derived from partial melting of the continental crust of different compositions during the exhumation.

We thank Professor Chen Yanjing (Peking University) for his help with our research. We are grateful to Professor Xu Xisheng and Zhang Wenlan (State Key Laboratory for Mineral Deposits Research, Nanjing University) for their assistance in zircon $\mathrm{U}-\mathrm{Pb}$ dating. This paper greatly benefited from constructive reviews of two anonymous reviewers. This work was supported by the Chinese Ministry of Science and Technology (2006CB403505).

1 Meng Q R, Zhang G W. Geologic framework and tectonic evolution of the Qinling orogen, central China. Tectonophysics, 2000, 323: 183-196

2 Ratschbacher L, Hacker B, Calvert A, et al. Tectonics of the Qinling (Central China): tectonostratigraphy, geochronology, and deformation history. Tectonophysics, 2003, 366: 1-53

3 Zhang G W, Zhang B R, Yuan X C, et al. Qinling Orogenic Belt and Continental Dynamics (in Chinese). Beijing: Science Press, 2001

4 Sun W D, Li S G, Sun Y, et al. Mid-paleozoic collision in the north Qinling: Sm-Nd, $\mathrm{Rb}-\mathrm{Sr}$ and ${ }^{40} \mathrm{Ar} /{ }^{39} \mathrm{Ar}$ ages and their tectonic implications. J Asian Earth Sci, 2002, 21: 69-76

5 Zhao Z F, Zheng Y F. Remelting of subducted continental lithosphere: Petrogenesis of Mesozoic magmatic rocks in the Dabie-Sulu orogenic belt. Sci China Ser D-Earth Sci, 2009, 52: 1295-1318

6 Zheng Y F. A perspective view on ultrahigh-pressure metamorphism and continental collision in the Dabie-Sulu orogenic belt. Chinese Sci
Bull, 2008, 53: 3081-3104

7 Zheng Y F, Chen R X, Zhao Z F. Chemical geodynamics of continental subduction-zone metamorphism: Insights from studies of the Chinese Continental Scientific Drilling (CCSD) core samples. Tectonophysics, 2009, 475: 327-358

8 Sun W D, Li S G, Chen Y D, et al. Timing of synorogenic granitoids in the South Qinling, Central China: Constraints on the evolution of the Qinling-Dabie orogenic belt. J Geol, 2002, 110: 457-468

9 Zhang C, Zhang G, Yan Y, et al. Origin and dynamic significance of Guangtoushan granitic plutons to the north of Mianlue zone in southern Qinling (in Chinese). Acta Petrol Sin, 2005, 21: 711-720

10 Li S G, Sun W D. A middle Silurian-early Devonian magmatic arc in the Qinling Mountains of central China: A discussion. J Geol, 1996, 104: 501-503

11 Meng Q R, Zhang G W. Timing of collision of the North and South China blocks: Controversy and reconciliation. Geology, 1999, 27: 123

12 Mattauer M, Matte P, Malavieille J, et al. Tectonics of the Qinling belt: Build-up and evolution of eastern Asia. Nature, 1985, 317: 497-500

13 Lai S C, Zhang G W. Geochemical features of ophiolite in MianxianLueyang suture zone, Qinling orogenic belt. J China Univ Geosci, 1996,7: 165-172

14 Lai S C, Zhang G W, Dong Y P, et al. Geochemistry and regional distribution of ophiolites and associated volcanics in Mianlüe suture, Qinling-Dabie Mountains. Sci China Ser D-Earth Sci, 2004, 47: 289299

15 Li S G, Sun W D, Zhang G W, et al. Chronology and geochemistry of metavolcanic rocks from Heigouxia Valley in Mianlue tectonic arc, South Qinling: Observation for a Paleozoic oceanic basin and its closure time. Sci China Ser D-Earth Sci, 1996, 39: 300-310

16 Liu F, Gerdes A, Liou J, et al. SHRIMP U-Pb zircon dating from Sulu-Dabie dolomitic marble, eastern China: constraints on prograde, ultrahigh-pressure and retrograde metamorphic ages. J Metamorph Geol., 2006, 24: 569-589

17 Liu F, Gerdes A, Zeng L, et al. SHRIMP U-Pb dating, trace elements and the Lu-Hf isotope system of coesite-bearing zircon from amphibolite in the SW Sulu UHP terrane, eastern China. Geochim Cosmochim Acta, 2008, 72: 2973-3000

18 Liu $\mathrm{F}$ L, Xu Z Q, Liou J G, et al. SHRIMP U-Pb ages of ultrahigh-pressure and retrograde metamorphism of gneisses, south-western Sulu terrane, eastern China. J Metamorph Geol, 2004, 22: 315-326

19 Liu F L, Xu Z Q, Xue H M. Tracing the protolith, UHP metamorphism, and exhumation ages of orthogneiss from the SW Sulu terrane (eastern China): SHRIMP U-Pb dating of mineral inclusion-bearing zircons. Lithos, 2004, 78: 411-429

20 Wan Y S, Li R W, Wilde S A, et al. UHP metamorphism and exhumation of the Dabie Orogen, China: Evidence from SHRIMP dating of zircon and monazite from a UHP granitic gneiss cobble from the Hefei Basin. Geochim Cosmochim Acta, 2005, 69: 4333-4348

21 Liu F, Xu Z. Fluid inclusions hidden in coesite-bearing zircons in ultrahigh-pressure metamorphic rocks from southwestern Sulu terrane in eastern China. Chinese Sci Bull, 2004, 49: 396-404

22 Yang J S, Wooden J L, Wu C L, et al. SHRIMP U-Pb dating of coesite-bearing zircon from the ultrahigh-pressure metamorphic rocks, Sulu terrane, east China. J Metamorph Geol., 2003, 21: 551-560

23 ZHANG C L, WANG T, WANG X X. Origin and tectonic Setting of the Early Mesozoic granitoids in Qinling Orogenic Belt (in Chinese). Geol J China Univ, 2008, 14: 304-316

24 Lu X X, Wei X D, Xiao Q H, et al. Geochronological studies of rapakivi granites in qinling and its geological implications (in Chinese). Geol J China Univ, 1999, 5: 372-377

25 Zhang Z Q, Zhang G W, Liu D Y. Isotopic Geochronology and Geochemistry of Ophiolites, Granites and Clastic Sedimentary Rocks in the Qinling Orogenic Belt (in Chinese). Beijing: Geological Publishing House, 2006. 1-348

26 Zhang Z Q, Zhang G W. Age of the Shahewan rapakivi granite in the Qinling Orogen, China, and its constraints on the end time of the main orogenic stage of this orogen. Chinese Sci Bull, 1999, 44: 2001-2001

27 Wang F, Lu X X, Lo C H, et al. Post-collisional, potassic monzonite-minette complex (Shahewan) in the Qinling Mountains (central 
China): ${ }^{40} \mathrm{Ar} /{ }^{39} \mathrm{Ar}$ thermochronology, petrogenesis, and implications for the dynamic setting of the Qinling orogen. J Asian Earth Sci, 2007, 31: 153-166

$28 \mathrm{Hu} \mathrm{J}$ M, Cui J T, Meng Q R. The U-Pb age of zircons separated from the Zhashui granite in Qinling orogen and its significance (in Chinese). Geol Rev, 2004, 50: 323-329

29 Qin J F, Lai S C, Wang J, et al. High- $\mathrm{Mg}^{\#}$ adakitic tonalite from the Xichahe area, South Qinling orogenic belt (Central China): Petrogenesis and geological implications. Int Geol Rev, 2007, 49: 1145-1158

30 Qin J F, Lai S C, Diwu C R, et al. Magma mixing origin for the post-collisional adakitic monzogranite of the Triassic Yangba pluton, Northwestern margin of the South China block: Geochemistry, Sr-Nd isotopic, zircon $\mathrm{U}-\mathrm{Pb}$ dating and $\mathrm{Hf}$ isotopic evidences. Contrib Mineral Petrol., 2010, 159: 389-409

31 Zhang H F, Xiao L, Zhang L, et al. Geochemical and Pb-Sr-Nd isotopic compositions of Indosinian granitoids from the Bikou block, northwest of the Yangtze plate: Constraints on petrogenesis, nature of deep crust and geodynamics. Sci China Ser D-Earth Sci, 2007, 50: 972-983

32 Zhang H F, Jin L L, Zhang L, et al. Geochemical and Pb-Sr-Nd isotopic compositions of granitoids from western Qinling belt: Constraints on basement nature and tectonic affinity. Sci China Ser DEarth Sciences, 2007, 50: 184-196

33 Jin W J, Zhang Q, He D F, et al. SHRIMP dating of adakites in western Qinling and their implications (in Chinese). Acta Petrol Sin, 2005, 21:959-966

34 Qin J F, Lai S C, Grapes R, et al. Geochemical evidence for origin of magma mixing for the Triassic monzonitic granite and its enclaves at Mishuling in the Qinling orogen (central China). Lithos, 2009, 112: 259-276

35 He Z Y, Xu X S, Yu Y, et al. Origin of the Late Cretaceous syenite from Yandangshan, SE China, constrained by zircon U-Pb and $\mathrm{Hf}$ isotopes and geochemical data. Int Geol Rev, 2009, 51: 556-582

36 Andersen T. Correction of common lead in $\mathrm{U}-\mathrm{Pb}$ analyses that do not report ${ }^{204} \mathrm{~Pb}$. Chem Geol, 2002, 192: 59-79

37 Ludwig K. Users Manual for Isoplot/Ex (rev. 2.49): A geochronological Toolkit for Microsoft Excel. Berkeley Geochronology Center, Special Publication, 2001

38 Hoskin P, Black L. Metamorphic zircon formation by solid-state recrystallization of protolith igneous zircon. J Metamorph Geol, 2000, 18: 423-440

39 McDonough W F, Sun S S. The composition of the Earth. Chem Geol, 1995, 120: 223-253

40 Keay S, Steele D, Compston W. Identifying granite sources by SHRIMP U-Pb zircon geochronology: An application to the Lachlan fold belt. Contrib Mineral Petrol, 1999, 137: 323-341

41 Zheng Y F, Zhang S B. Formation and evolution of Precambrian continental crust in South China. Chinese Sci Bull, 2007, 52: 1-12

$42 \mathrm{Li} \mathrm{X} \mathrm{H.} \mathrm{U-Pb} \mathrm{zircon} \mathrm{ages} \mathrm{of} \mathrm{granites} \mathrm{from} \mathrm{the} \mathrm{southern} \mathrm{margin} \mathrm{of} \mathrm{the}$ Yangtze Block: Timing of Neoproterozoic Jinning: Orogeny in SE China and implications for Rodinia Assembly. Precambrian Res, 1999, 97: 43-57

43 Li Z X, Zhang L, Powell C. South China in Rodinia: part of the missing link between Australia-East Antarctica and Laurentia? Geology, 1995, 23: 407

44 Wu R X, Zheng Y F, Wu Y B, et al. Reworking of juvenile crust: Element and isotope evidence from Neoproterozoic granodiorite in South China. Precambrian Res, 2006, 146: 179-212

45 Zhang S B, Zheng Y F, Zhao Z F, et al. Origin of TTG-like rocks from anatexis of ancient lower crust: Geochemical evidence from Neoproterozoic granitoids in South China. Lithos, 2009, 113: 347-368

46 Zhou M F, Yan D P, Wang C L, et al. Subduction-related origin of the 750 Ma Xuelongbao adakitic complex (Sichuan Province, China): Implications for the tectonic setting of the giant Neoproterozoic magmatic event in South China. Earth Planet Sci Lett, 2006, 248: 286-300

47 Zhao J H, Zhou M F. Geochemistry of Neoproterozoic mafic intrusions in the Panzhihua district (Sichuan Province, SW China): Implications for subduction-related metasomatism in the upper mantle. Precambrian Res, 2007, 152: 27-47

48 Zheng Y F, Fu B, Gong B, et al. Stable isotope geochemistry of ultrahigh pressure metamorphic rocks from the Dabie-Sulu orogen in China: implications for geodynamics and fluid regime. Earth Sci Rev, 2003, 62: 105-161

49 Zheng Y F, Wu Y B, Chen F K, et al. Zircon U-Pb and oxygen isotope evidence for a large-scale ${ }^{18} \mathrm{O}$ depletion event in igneous rocks during the Neoproterozoic. Geochim Cosmochim Acta, 2004, 68: 4145-4165

50 Tang J, Zheng Y F, Wu Y B, et al. Zircon U-Pb age and geochemical constraints on the tectonic affinity of the Jiaodong terrane in the Sulu orogen, China. Precambrian Res, 2008, 161: 389-418

51 Zheng Y F, Wu R X, Wu Y B, et al. Rift melting of juvenile arc-derived crust: Geochemical evidence from Neoproterozoic volcanic and granitic rocks in the Jiangnan Orogen, South China. Precambrian Res, 2008, 163: 351-383

52 Li Z X, Li X H, Kinny P D, et al. Geochronology of Neoproterozoic syn-rift magmatism in the Yangtze Block, South China and correlations with other continents: evidence for a mantle superplume that broke up Rodinia. Precambrian Res, 2003, 122: 85-109

53 Barbarin B. A review of the relationships between granitoid types, their origins and their geodynamic environments. Lithos, 1999, 46: 605-626

54 Whalen J, Currie K, Chappell B. A-type granites: geochemical characteristics, discrimination and petrogenesis. Contrib Mineral Petrol., 1987, 95: 407-419

55 Tepper J, Nelson B, Bergantz G, et al. Petrology of the Chilliwack batholith, North Cascades, Washington: generation of calc-alkaline granitoids by melting of mafic lower crust with variable water fugacity. Contrib Mineral Petrol., 1993, 113: 333-351

56 Yang J H, Chung S L, Wilde S A, et al. Petrogenesis of post-orogenic syenites in the Sulu Orogenic Belt, East China: geochronological, geochemical and Nd-Sr isotopic evidence. Chem Geol, 2005, 214: 99-125

57 Chen J F, Xie Z, Li H M, et al. U-Pb zircon ages for a collision-related K-rich complex at Shidao in the Sulu ultrahigh pressure terrane, China. Geochem J, 2003, 37: 35-46

58 Zhao Z F, Zheng Y F, Chen R X, et al. Element mobility in mafic and felsic ultrahigh-pressure metamorphic rocks during continental collision. Geochim Cosmochim Acta, 2007, 71: 5244-5266

59 Zheng X S, Jin C W, Zhai M G, et al. Petrochemistry and tectonic background of the gray gneisses in north Dabie terrane (in Chinese). Acta Petrol Sin, 1999, 15: 350-358

60 Ma C, Ehlers C, Xu C, et al. The roots of the Dabieshan ultrahigh-pressure metamorphic terrane: constraints from geochemistry and Nd-Sr isotope systematics. Precambrian Res, 2000, 102: 279-301

61 Lai S C, Liu C Y, Yi H S. Geochemistry and petrogenesis of Cenozoic andesite-dacite associations from the Hoh Xil region, Tibetan plateau. Int Geol Rev, 2003, 45: 998-1019

62 Lai S C, Zhang G W, Li S Z. Ophiolites from the Mianlue Suture in the southern Qinling and their relationship with the eastern Paleotethys evolution. Acta Geol Sin, 2004, 78: 107-117

63 Davies H J, von Blanckenburg F. Slab breakoff: A model of lithosphere detachment and its test in the magmatism and deformation of collisional orogens. Earth Planet Sci Lett, 1995, 129: 85-102

Open Access This article is distributed under the terms of the Creative Commons Attribution License which permits any use, distribution, and reproduction in any medium, provided the original author(s) and source are credited. 